\title{
The Role of Firm's Location, Export-Related Resources and Capabilities in Relation to Coffee \& Sesame Export Performance in Ethiopia
}

\author{
Getie Andualem Imiru ${ }^{1}$ \\ ${ }^{1}$ School of Commerce, College of Business and Economics, Addis Ababa University, Ethiopia \\ Correspondence: Dr Getie Andualem Imiru, Associate Professor in Marketing Management, School of Commerce, \\ College of Business and Economics, Addis Ababa University, Ethiopia.
}

Received: August 17, 2021

Accepted: September 13, $2021 \quad$ Online Published: September 17, 2021

doi:10.5430/ijba.v12n5p47

URL: https://doi.org/10.5430/ijba.v12n5p47

\begin{abstract}
Exporting has been one of the fastest foreign expansion strategies in the last two decades. The purpose of this study is to investigate the role of an exporter's location in the development of export-related resources and capabilities, which will have an impact on the degree of export performance. The relationship between export-related resources, capabilities, and export performance are examined in this study. A total of 300 questionnaires were sent out to coffee and sesame exporters. However, only 253 surveys were used for analysis. The SmartPLS 3 software was used to analyse the data using the Partial Least Squares (PLS) technique. The study's findings suggest that access to location-specific resources and skills are critical antecedents for a company's ability to build export-related resources and capabilities in order to improve export performance. The geographic location of a company has a considerable and beneficial impact on human resource capability $(\beta=0.67, \mathrm{p}=0.001)$. Information capability was not significantly influenced by human resource capability $((\beta=0.082, \mathrm{P}=0.259)$. Information capability $((\beta=0.656, \mathrm{p}=0.001)$ is significantly influenced by organizational planning capability $((\beta=0.452, \mathrm{p}=0.001)$. Satisfaction Export Performance $((\beta=0.431, \mathrm{p}=0.01)$ has been significantly and positively influenced by information capability. New Product Development Capability influences strategic export performance significantly and positively $((\beta=0.330, p=0.001)$. Strategic export performance $((\beta=-0.035, \mathrm{P}=0.820)$ and satisfaction with export performance $((\beta=0.050, \mathrm{P}=0.625)$ were not affected by relationship capability. These data suggest that when it comes to exporting, rural businesses face significantly greater obstacles than those in metropolitan areas. The outcomes of this study will assist managers of remote-area businesses in developing equally appealing recruitment and reward practices in order to compete with businesses in urban areas. Furthermore, the outcomes of this study advise that export firm managers think carefully about the resources and capabilities required to improve their export performance.
\end{abstract}

Keywords: location advantage, export related -resources, relational capability, informational capability, export capability, strategic export performance, satisfaction with export performance

\section{Introduction}

The influence of a company's location has been investigated in many export performance studies (Sousa et al. 2008). Access to government and other export-related services, accumulated experience, information and support systems; specialized infrastructure; labour market attributes and other market networks are all associated to company location in the commercial sector (Fuller-Love et al., 2006; Hoogstra and Van Dijk, 2004). Costa Campi et al. (2004) argued that Exporting companies located in metropolitan areas have a lower cost of access to foreign markets due to the availability of specialized infrastructures, a substantial number of intellectuals, a network of suppliers, specialized labour as well as the existence of an increased number of exporters in the same location. Freeman et al. (2012) stated that Location can be perceived as a resource acquisition and capability development enabler in the context of exporting. Metropolitan areas attract clusters of firms in the same and related industries, enabling SMEs to benefit from knowledge spill overs and compete more effectively in the global markets (Mittelstaedt et al., 2006). Despite the fact that exporting is acknowledged as a crucial engine for firms growth, the distinctions between exporting firms headquartered in distant and metropolitan locations have been under-researched (Katsikeas et al., 2000; Mittelstaedt et al., 2006). Because of the geographic remoteness and small population, distant locations have unique obstacles in terms of economic development (Atherton and Hannon (2006). 


\section{Statement of the Problem}

Ethiopia is usually regarded as the origin of coffee. The flavour is unique, delicate, and delicate; notes of jasmine blossom, bergamot, and blueberry can be detected in the aftertaste of Ethiopian coffee. Ethiopian coffees are either rich and winey, or flowery and tea-like. Consumers in a variety of coffee-importing countries hold Ethiopian coffee in high regard. Ethiopian coffee exports for the 2019/20 marketing year was around 3.9 million bags (234,000 metric tons). Oil seeds are also an important part of Ethiopia's rural and national economies. Oil seeds are Ethiopia's second most important export crop, after coffee (Monitor Group, 2012). Sesame is the second most important agricultural commodity, behind coffee, in terms of foreign exchange earnings, with around $\$ 449$ million. However, coffee and sesame growers and exporters face hurdles as a result of weak marketing infrastructure or, in certain cases, the lack of marketing infrastructure. Furthermore, the key exportable agricultural products exporting enterprises headquartered in faraway and urban places, such as coffee and sesame, have been under-researched. As a result, the purpose of this study was to look into the function of location advantage in terms of export-related resources and capabilities in relation to Ethiopian coffee and sesame export performance.

\section{Literature Review}

\subsection{Theoretical Review}

\subsubsection{The Resource-Based Theory}

In the literature on export performance, the Resource-Based Theory (RBV) is a major theoretical model (Cadogan et al., 2009; Freeman et al., 2012; Lages et al., 2009a). The resource-based view (RBV) is a management approach for determining which strategic resources a firm may use to gain a competitive advantage over time. As per RBV paradigm, a firms can enjoy and keep a competitive edge by deploying valuable inelastic resources and skills (Fang and Zou, 2009; La et al., 2009; Ray et al., 2004).To stay competitive, a company's resources and capabilities must be valuable and capable of exploiting opportunities and neutralizing threats in the environment; uncommon among current and potential competitors; difficult to imitate and distinguish from competitors; and there should be no equivalent substitutes for this resource (Barney et al., 2001; Westhead et al., 2002). In the export literature, tangible and intangible resources such as technological, financial, human, physical, and organizational assets have been identified (Bakar and Ahmad, 2010; Loane and Bell, 2006).

\section{Financial Resources}

The term "financial resources" refers to the ability to obtain cash and capital, both of which are necessary for exporting (Morgan et al., 2004). Some small businesses must make commitments in order to invest in export operations (Leonidou et al., 2004).To improve export performance, financial resources can be obtained by developing solid partnerships with financial institutions (Leonidou et al., 2004). Morgan et al. (2004) argued financial resources must be assessed in relation to the amount and convenience with which an export business can obtain financing.

\section{Informational Resources}

The process of gathering and disseminating information about consumers, rivals, distribution networks, and the export market is known as knowledge acquisition (Katsikeas and Morgan 1994). Knowledge is divided into explicit and implicit categories, with explicit knowledge requiring training and education and implicit knowledge requiring experience (Nonaka, 1991).

\section{Relational Resources}

The networks between the firm and other entities such as consumers, suppliers, competitors, and government institutions are characterized as relational resources (Davis and Mentzer, 2008). Companies are striving to construct and grow a strong value network in order to achieve a competitive advantage in a globalized economy (Davis and Mentzer, 2008)

\section{Dynamic Capabilities}

The term "dynamic" was coined by Teece et al. (1997, p.515) to describe the "ability to refresh competencies in order to achieve congruence with the changing business environment." Dynamic capabilities are also defined as a company's ability to integrate, build, and reconfigure internal and external competencies in order to respond quickly to changes in the business environment (Teece, 2007). Long-term superior performance can be achieved by companies with dynamic capacities. Dynamic capability, according to WU (2006), is a mediating component between organizational resources and performance. In order to retain consistency between their strategy and the business reality, companies must increase their ability to renew capabilities. 


\section{Export Performance}

Export performance is inextricably linked to the availability of resources and capabilities for export markets, as well as the firm's geographic advantage (Morgan et al., 2004). To evaluate export performance, objective and subjective measures can be utilized (Sousa et al., 2008). Subjective metrics include export success and perceived pleasure with export sales, whereas objective measures include export intensity, volume of export sales, and export market share (Sousa et al., 2008). According to the RBV, Firms are viewed as unique bundles of tangible and intangible resources that may be used to plan and implement methods to increase their efficiency and effectiveness (Wernerfelt, 1984; Barney, 1991). Taking advantage of an organization's strategic resource capabilities can explain variances in performance (Eisenhardt and Martin, 2000; Makadok, 2001). To obtain a competitive advantage in the export market, exporting enterprises make use of available firm-specific resources and competences (Kaleka, 2002).

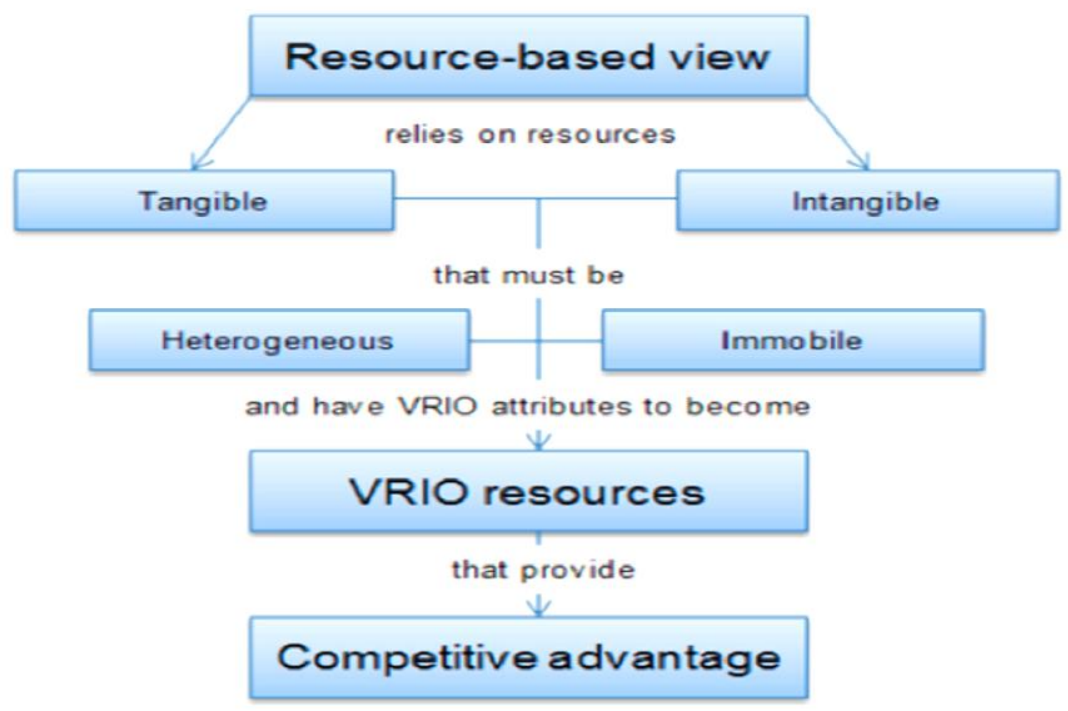

Figure 1. The Resource based view and competitive advantage

The Resource-Based View (RBV) investigates the relationship between a company's internal characteristics and its performance, and the VRIO Framework or VRIO Model is part of that perspective.

IS THE RESOURCE OR CAPABILITY...?

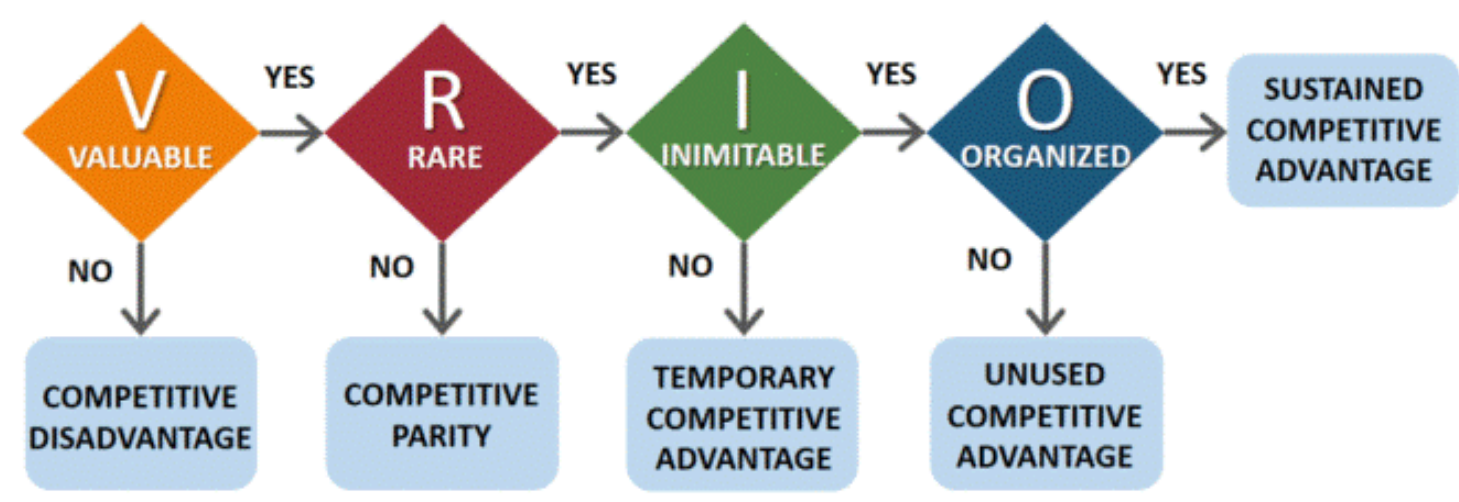

Figure 2. The VRIO framework 
According to the RBV, resources are considered valuable when they enable a company to implement strategies that increase efficiency and effectiveness by taking advantage of opportunities or avoiding dangers. To be deemed rare, resources must be acquired by only one or a few organizations. Resources should also be difficult to duplicate or substitute and focal company must be capable of successfully assembling and coordinating resources.

\subsubsection{Institutional Theory}

By addressing context-specific difficulties, the institutional theory complements the RBV (Peng et al. 2009). The integration of institutional theory with the RBV has been heavily urged due to the substantial influence of institutions on enterprises' resource decisions (Barney et al. 2001; Oliver 1997). The interaction of institutional determinants with business resources and capabilities, on the other hand, has only been little researched in order to better understand the export performance phenomenon. The major goal of this study is to discover the role of institutional and resource-based factors in influencing export performance, depending primarily on the institutional theory and resource-based approach.

\subsection{Empirical Literature Review}

There really is a link between organizational resources, capabilities, systems and competitive advantage, according to previous study (Barney, 2001a; 2001b; 2007; Priem \& Butler, 2001a; 2001b; Wiklund \& Shepherd, 2003; Morgan, Kaleka, \& Katsikeas, 2004; Sirmon, Hitt, \& Ireland, 2007). Many studies have demonstrated that capabilities and competitive advantage have a strong association (Barney, 2001a; 2001b; Colotla, Shi, \& Gregory, 2003; Wang \& Lo, 2003; Morgan et al., 2004; Ray, Barney, \& Muhanna, 2004; Perez-Freije \& Enkel, 2007; Sirmon et al., 2007). Organizational skills and collective learning, core competencies, resource development competence, organizational integration, strategic decision making, alliance-building, product development, relationship-building, informational and innovation capabilities are some of the concepts and categories used to describe and categorize capabilities (Eisenhardt \& Martin, 2000; Helfat \& Peteraf, 2003).

\section{Location and Human Resources}

According to the human capital theory, managers with greater experience can make better strategic decisions (Shrader and Siegel, 2007). Experienced managers have a broader market understanding, which can be a differentiator between exporters and non-exporters (Crick and Spence, 2005; Manolova et al., 2002). Metropolitan areas offer advantages to businesses looking to lower their costs of doing business, such as access to a larger and more educated pool of human resources (Mittelstaedt et al., 2006). For organizations engaged in export marketing, management experience, are a significant element since competitive practices are more sophisticated than those used domestically (De Toni and Nassimbeni, 2001; La et al., 2009; Manolova et al., 2002).

H-1. Location advantages have a significant and positive impact on a company's ability to build export-related human Resource.

\section{Location and Organizational Planning}

Slotegraaf and Dickson (2004) stated that strategic planning promotes the process of achieving and maintaining alignment between a firm and its export environment. Shoham et al. (2002) argued Export planning strategy was found to be a significant explanatory variable to coordinate and support diverse export markets. Organizational planning allows businesses to deal effectively with ever-changing environmental changes (Alpkan et al., 2007; Knight and Kim, 2009). Darling and Seristo (2004) stated that Companies must have export-specific strategic planning and coordination processes to be successful in a foreign market.

H-2. Location advantage has a significant and positive impact on the firm's ability to develop export-related organizational planning.

\section{Resources and information capability}

In the export literature, the combination of resources and capability development is highly valued for export market (Morgan and Hunt, 1999). Exporting enterprises can discover opportunities and respond swiftly to improve their export performance by combining internal firm assets (available resources) with market-based assets (capability development) (Barney, 1991; Crick and Spence, 2005). Making effective and efficient export market operations requires substantial amount information capability (Leonidou and Theodosiou, 2004; Toften, 2005). The gathering of unique, important, and difficult-to-replace market information has the potential to boost a company's international competitive advantage (Goll et al., 2007; Loane and Bell, 2006).

A high level of information capability is required to conduct effective and efficient export market operations (Leonidou and Theodosiou, 2004; Toften, 2005). The gathering of one-of-a-kind, critical, and difficult-to-replace 
market data has the capacity to advance a company's international competitive advantage (Goll et al., 2007; Loane and Bell, 2006). The need to analyse competitors' products is facilitated by the uniqueness of information, inimitable information helps to protect earnings, and immobility decreases the risk of knowledge being spread to rival enterprises (Knight and Cavusgil, 2004). If a corporation has the resources to create the market intelligence capabilities needed to function in a volatile environment, it will reduce unfamiliarity with export markets and reduce risk in the export venture (Gumede and Rasmussen, 2002)

H-3. Export-related human resource has a significant and a positive influence on an information capability.

H-4. Export-related organizational resource has a significant and a positive influence on an information capability.

\section{Resources and Relationship Capability}

Relationship capabilities are a set of intangible assets that reflect a sequence of interactions that take place between the interconnected parties involved in an export venture relationship (Lages et al. 2009a). Because exporting entails multiple contacts between parties and is not limited to the exchange of goods for money, export management focuses with enterprises' connections with overseas channel members (Fung et al., 2007).Exporting companies rely on the development of connections or relationships to expedite the collection of information, the identification of market prospects and the testing of new products and marketing concepts (Lages et al., 2009a; Matanda and Freeman, 2009). To achieve superior export performance, a company's human and organizational resources are vital in creating the capacity to identify, qualify, develop, and maintain solid relationships with overseas agents and/or distributors (Freeman et al., 2006; Leonidou et al., 2002).

H-5: Export-related human resource has a significant and a positive influence on relationship capability.

H-6: Export-related organizational resource has a significant and positive influence on relationship capability.

\section{Resources and New Product Development}

The knowledge-based view assumes that knowledge is inherent in human capital, allowing businesses to improve their unique talents in order to produce new goods and services (Chen and Huang, 2009).Morgan et al. (2004) suggested that a company's ability to give superior value to its target market is influenced by its new product development capabilities. According to De Brentani (2001), new product creation is critical for a company's long-term survival and success. The ability of an organization to innovate is inextricably linked to its intellectual capital, or its ability to draw on its human capital resource base (Subramaniam and Youndt, 2005).

H-7. Export-related Human Resource has a significant and a positive influence on New Product Development.

H-8. Export-related Organizational Resource has a significant and a positive influence on New Product Development.

\section{Information capability and Export performance}

Making effective and efficient export market decisions requires a high degree of information competence (Leonidou and Theodosiou, 2004; Toften, 2005). The collection of unique, important, and difficult-to-replace market information has the potential to boost a company's international competitive advantage (Goll et al., 2007; Loane and Bell, 2006; Srivastava et al., 1998).The need to analyse competitors' offerings is facilitated by the uniqueness of information, inimitable information helps maintain earnings, and immobility reduces the risk of knowledge being spread to rival enterprises (Knight and Cavusgil, 2004). To that end, having access to relevant, reliable, and timely data is critical for businesses to plan effectively and respond to changing export markets.

H-9: Information capability has a significant and a positive influence on strategic export performance.

H-10: Information capability has a significant and a positive influence on satisfaction with export performance.

\section{Relationship capability and Export performance}

A small number of researchers found market-based assets to be more valuable than corporate resources. (Doole et al., 2006; Ibeh, 2003; Morgan et al., 2004; Sapienza et al., 2006); Ibeh, 2003; Morgan et al., 2004; Sapienza et al., 2006). When it came to having information, relationships, and product development capabilities, there was a significant difference between high and low export performance (Piercy et al. (1998). Relational elements such as human touch, communication with channel members, and maintaining positive working relationships with distributors have all increased the likelihood of export success (Langes et al., 2009a; Styles and Ambler, 2000). A relational capability accelerates knowledge access, supports innovation, and facilitates market entry, resulting in a competitive advantage (Nuryakin, 2018; Nuryakin \& Ardyan, 2018). Smirnova et al. (2011) suggest that improving relational capability might be used as a proxy for leveraging performance. 
H-11: Relationship Capability has a significant and a positive influence on strategic export performance

H-12: Relationship Capability has a significant and a positive influence on satisfaction with export performance.

Product development competence refers to a company's ability to create and launch new products in order to meet the needs of international markets (Zou etal; 2003). According to Avlonitis and Salavou (2007), enterprises must produce new products or alter existing products on a regular basis to obtain or maintain their competitive edge and deliver new items with greater originality in order to achieve better long-term export success. Subjective metrics of export performance are commonly used by researchers to assess perceived export success and satisfaction (Zou et al., 1998). Product development is favourably linked to performance. (Leonidou et al. (2002). Firms with great product development and innovation capabilities might put their other assets to work improving existing product advantage in export markets (Clark and Fujimoto, 1991). Export venture managers use available firm-specific resources and capabilities to acquire a competitive position in the export market (Kaleka, 2002).

H-13: New product development capability has a significant and a positive influence on strategic export performance.

H-14: New product development capability satisfaction with export performance.

\subsection{Conceptual Framework of the Study}

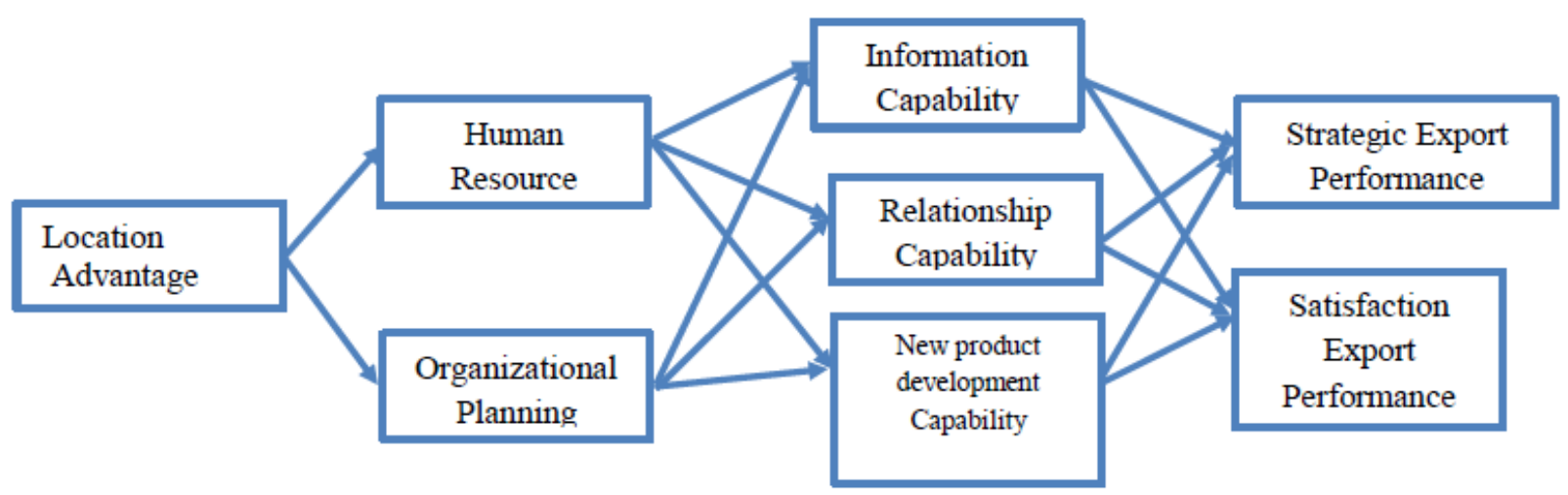

Figure 3. Own research model

\section{Research Methodology}

Methodology is indicates the underlying principles and methods of organizing and the systems of inquiry procedure leading to completion of the study. Methodological issues relating to study population, the sample unit, sample size, sources of data and analysis of data used in the study are reported below.

\subsection{Description of the Coffee and Sesame Sector in Ethiopia}

Ethiopia is widely considered the birthplace of coffee. The flavour is inimitable, sensitive and delicate; from Ethiopian coffee one can sense notes of jasmine flower, bergamot and blueberry in aftertaste. The body of the coffee is not very strong and acidity is mild and pleasant. In general, Ethiopian coffees are heavy and winey or floral and tea like. Ethiopian coffee is highly valued by consumers in a range of coffee importing countries. Within Ethiopia, there are three main growing regions - Harrar, Ghimbi and Sidamo (also known as Yirgacheffe). Almost all coffee in Ethiopia is cultivated on small farms with the exception of some larger, government run estates. Ethiopia exports its Arabica Coffee to Europe, Asia, and America, Australia and Middle East and other parts of the world. Coffee is Ethiopia's most important export commodity, accounting for about 29 percent of the value of all exports in $2018 / 19$. For the 2019/20 marketing year, experts say Ethiopian exports reached around 3.9 million bags of coffee (234,000 metric tons)....

Oil seeds are a mainstay of the rural and national economy in Ethiopia. The oil seeds are the second most export crops next to coffee in Ethiopia (Monitor Group (2012). Among the different oil crops, sesame is the second most important agricultural commodity next to coffee in foreign exchange earning to more than $\$ 449$ million. Sesame is also one of the major commercial grain crops agricultural products of Ethiopia. It is one of the oil seeds, the country 
has been producing in the Northern parts of Ethiopia mainly in Amhara and Tigray regions mainly Gondar area. ... About 44 percent of sesame seed production comes from Amhara region of Ethiopia. Some literatures indicate that sesame might be originated in Eastern Africa, mainly, Ethiopia. Hence, Ethiopia is rich in sesame genetic diversity. In Africa, Sudan is the major sesame producer followed by Nigeria, Somalia, Uganda and Ethiopia. Sesame production in the world is estimated at 2.25 million tons, of which $70 \%$ is consumed in the producing countries; with annual trading volume estimation of 600,000 mt worth US $\$ 500$ million (Abera H. 2009). Ethiopia is one of the major sesame growing and exporter countries in Africa, exporting huge produce to the world market. Israel has emerged as the top export destination for Ethiopian sesame seed, followed by China and UAE.

\subsection{Target Population of the Study}

The target population of the study comprises all Coffee and sesame exporters in major cities in Ethiopia including the capital city with a minimum of 5 years' experience in the export business.

\subsection{Sampling Unit}

This study targeted Coffee and sesame exporters in Ethiopia primarily in Addis Ababa as well as other major cities in the country. The sampling frame for this study was all actively registered coffee and sesame exporters in Ethiopia. The researcher had access to an appropriate database of 300 exporters located in Ethiopia representing firms with diverse export experience, geographic spread that ensures variance in location effects. Out of the 300 questionnaires sent, 260 were returned. All but 7 of the questionnaires were discarded resulting in an $84.3 \%$ real response rate was achieved.

\subsection{Sampling Technique}

The sampling technique used in this study is purposive sampling bearing in mind the homogeneous attribute of the target participants. All study participants were selected on the basis of 5 years' experience in the export business.

\subsection{Sample Size}

Although a total of 300 questionnaires were distributed to active coffee and sesame exporters. Only 253 usable questionnaires were returned at the end of the data collection process, which gave the response rate of $84 \% .47$ exporters declined to fill the questionnaires after being approached by the data collectors.

\subsection{Research Instruments}

This study used a research instrument developed and adopted from previously validated scales by further contextualizing it. All items were assessed using a five-point Likert-type scale, ranging from 1 to 5, where 1 denotes "strongly disagree", and 5 represents "strongly agree". All constructs were measured by multiple-item scales based on previous studies in the export performance literature.

\begin{tabular}{lcl}
\hline \multicolumn{1}{c}{ Constructs /Variables } & $\begin{array}{c}\text { Number of } \\
\text { Items }\end{array}$ & \multicolumn{1}{c}{ Source Adapted } \\
\hline Location advantage & 4 & Freel (2000) and Westhead (1995) \\
Human Resources capability & 3 & Morgan et al. (2004) \\
Organizational Planning & 3 & Li and Ogunmokun (2001), \\
Information, Capabilities & 3 & Morgan et al. (2004) and Piercy et al. (1998). \\
Relationship Capabilities & 3 & Morgan et al. (2004) and Piercy et al. (1998). \\
New Product Development Capabilities & 5 & Morgan et al. (2004) and Piercy et al. (1998). \\
Strategic Export Performance & 6 & was adapted from Cavusgil and Zou (1994) and Styles \\
Satisfaction With Export Performance & 5 & Robertson and Chetty (2000) and Cadogan et al. (2002). \\
\hline
\end{tabular}

30 questionnaires were distributed to target exporters before being sent to all study participants to measure the level of understand ability, reliability, and validity. With an 83.3 percent response rate, 25 of the 30 questionnaires were returned fully completed. For surveys delivered and collected for a pilot test, a $30 \%$ response rate was reasonable 
((Saunders et al. (2009). The purpose of the pilot study was to see if respondents understood the survey questions and to get comments on how to improve the instrument. Editable questionnaires were obtained for pilot testing (Kothari, 2004). Except for a few adjustments that were in fact implemented into the main questionnaire, the responses indicated that the questionnaire was generally easy to complete.

\subsection{Data Collection Procedure}

Every exporter at major banks, as well as their offices in Ethiopia's capital and other key cities, was personally approached by the field data collectors. To get a qualified answer for the questionnaire, the data collectors employed a screening question to see if they had been in the export business for at least 5 years.

\subsection{Data Analysis}

The research model was examined using the Partial Least Squares (PLS) technique and the SmartPLS 3 software (Ringle, Wende \& Becker, 2018). Using Anderson and Gerbing's (1988) two-stage analytical methodology, investigation was made to measure the validity and reliability of the data before examining the structural model (testing the predicted relationship) (see Hair et al., 2017; Ramayah, 2017). The importance of the path coefficients and loadings was also tested using a method (5000 resamples) (Hair et al., 2017).

\section{Results and Discussion}

\subsection{Non-Response Bias}

This study used 50\% of the collected data half of which are early respondents and the other half are late respondents. For practically all of the elements, the t-tests revealed (98.24 percent). There was no statistically significant difference between the early and late respondents $(p>.05)$ in the test. This suggested that the data was free of non-response bias.

\subsection{Demographic Profile}

Despite the fact that 300 questionnaires were sent, only 253 were returned at the end of the data collection process, resulting in an $84.3 \%$ response rate. When it came to years of experience in the foreign market, $42 \%$ of the respondents had between 11 and 20 years of experience, 41 percent had between 6 and 10 years, 17 percent had above 20 years. Similarly, 32\% of companies said they operate in 1 to 3 export markets, $30 \%$ in 7 to 10 markets, and $28 \%$ in 4 to 6 export markets. Furthermore, agricultural items are exported by 78 percent of respondents, while industrial products are exported by 22 percent. This implies the answers given are more or less based on understanding since the majority of the exporters are over 11 years of experience.

Table 1. Profile of respondents

\begin{tabular}{clcc}
\hline Item & \multicolumn{1}{c}{ Description } & Frequency & \% \\
\hline & $6-10$ & 85 & $41 \%$ \\
& $11-20$ & 89 & $42 \%$ \\
& Above 20 years & 43 & $17 \%$ \\
& Total & 253 & $100 \%$ \\
Number of Markets The Firm Operates & $1-3$ & 80 & $32 \%$ \\
& $4-6$ & 70 & $28 \%$ \\
& $7-10$ & 76 & $30 \%$ \\
Type of Products Exported & More than 10 years & 27 & $11 \%$ \\
& Total & 253 & $100 \%$ \\
& Coffee Exporters & 178 & $70.35 \%$ \\
& Sesame Seeds Exporters & 75 & $29.64 \%$ \\
& Total & 253 & $100 \%$ \\
\hline
\end{tabular}




\subsection{Structural Model Results}

The research model was analysed using the partial least squares (PLS) technique and the SmartPLS 3 software (Ringle, Wende \& Becker, 2018). Hair et al. (2017) employed Anderson and Gerbing's (1988) two-stage analytical processes to assess the measurement models' validity and reliability, followed by an examination of the structural model's hypothesized association testing (Hair et al., 2017).

\subsection{Measurement Model}

The data was first entered into SPSS and a preliminary stage of measurement item was identified before utilizing the SMART-PLS statistical tool to analyse it. SMART-PLS was then used to assess the assessment model's psychometric qualities in terms of internal consistency, reliability, convergent validity, and discriminant validity. Similarly, SPSS version 20 was used to verify the sampling adequacy (0.808) and overall Cronbach alpha (0.925) reliability measures. SMART PLS uses factor analysis as a data reduction technique. From the 32 original items, 10 were found to have a lower loading than the minimum of 0.50 for a sample of 253 or more (Hulland 199, P 198) and were eliminated. As a result, 22 items were used in this research. Reflective indicator loadings greater than 0.5 are regarded as good indicators of latent variables construct. Convergent and discriminant validity were evaluated and reported in order to evaluate the measurement model.

\subsection{Reliability and Convergent Validity}

The loadings, average variance extracted (AVE), and composite reliability are commonly used to determine the measurement's convergent validity (Gholami et al., 2013; Rahman et al., 2015). The loadings were all greater than 0.799, the composite reliabilities were all greater than 0.799, and all constructs' AVEs were greater than 0.5. (See Tables 2, 3, and 4 for more information.) When the question-statements linked with each latent variable are understood in the same way by various responders, a measurement instrument has high reliability. All of the Cronbach alpha coefficients used to assess the items' unidimensionality were more than 0.7 (range from 0.729 to 0.918), indicating strong internal consistency. Cronbach alpha, on the other hand, is based on the limiting assumption that all signs are equally important. Another way to look at dependability is to think of it as the proportion of measure variance that can be attributed to the underlying dimension (Werts et al. 1974). The assumption of parallel measures, according to Cronbach's alpha, represents a lower bound estimate of internal consistency, but the composite reliability provides a superior approximation (Chin et al. 1996, p.33). Composite reliability of all latent variables, on the other hand, was found above 0.7 ranging from 0.799 to 0.943 for all measures. Dhillon Goldstein rho measures internal consistence (ranging from 0.0 .716 to 0.925 ) like composite reliability which is acceptable above 0.7 (Gefen, 2000). The composite dependability of all latent variables, on the other hand, was found to be over 0.7 for all measurements, ranging from 0.799 to 0.943 . Internal consistency (range from 0.0.716 to 0.925) is measured by the Dhillon Goldstein rho, which is satisfactory above 0.7 (Gefen, 2000). Composite dependability above 0.7 is acceptable (Gefen, 2000). The average variance extraction (AVE) of all variable was found above the threshold value of 0.5 . The most frequently recommended threshold value of AVE to be of an acceptable validity is 0.5 (Fornell \& Larcker, 1981).

Table 2. Reliability analysis

\begin{tabular}{lcccc}
\hline & Cronbach's Alpha & rho_A & Composite Reliability & $\begin{array}{c}\text { Average Variance } \\
\text { Extracted (AVE) }\end{array}$ \\
\hline FIRMLO & 0.918 & 0.925 & 0.943 & 0.804 \\
HRCAP & 0.732 & 0.738 & 0.882 & 0.788 \\
INFOCAP & 0.781 & 0.786 & 0.819 & 0.603 \\
NPDCAP & 0.733 & 0.731 & 0.838 & 0.722 \\
ORGPLAN & 0.796 & 0.716 & 0.830 & 0.620 \\
RELACAP & 0.807 & 0.847 & 0.884 & 0.717 \\
SATISFEP & 0.864 & 0.788 & 0.811 & 0.589 \\
STREXPOP & 0.729 & 0.722 & 0.799 & 0.669 \\
\hline
\end{tabular}




\subsubsection{Construct Validity}

The construct validity of a set of measures determines if they are true constructs that describe an event (Straub, 1989). The methods for determining an instrument's construct validity can be divided into two categories: The degree to which multiple attempts to measure the same concepts agree with an AVE greater than 0.5 is referred to as convergent validity. The degree to which discriminant validity exists is referred to as discriminant validity.

\subsubsection{Discriminant Validity}

The Fornell-Larcker criterion can also be used to establish discriminant validity using AVE. The square root of AVE for any latent variable should be greater than its correlation with any other latent variable. This means that the variance shared by each latent variable with its block of indicators is greater than the variance shared by any latent variable with any other latent variable. The square root of AVE occurs in the diagonal cells of the Fornell-Larcker criterion table in SmartPLS output, and correlations appear below it. In absolute value terms, discriminant validity exists if the top number (which is the square root of AVE) in any factor column is greater than the numbers (correlations) below it. As seen in table 3, the square root of AVE or correlation is placed on the table's diagonal. There is no discriminant value concern if the correlation value is higher than the other values in the column. For example, the latent variable 'FIRMLO' AVE is discovered to be 0.804 in this study, hence its square root is 0.897 . This number is higher than the numbers in the Inform' column for correlation. The outcome suggests that discriminant validity is well-established.

Table 3. Latent variable correlation and discriminant validity

\begin{tabular}{|c|c|c|c|c|c|c|c|c|}
\hline & FIRMLO & HRCAP & INFOCAP & NPDCAP & ORGPLAN & RELACAP & SATISFEP & STREXPOP \\
\hline FIRMLO & 0.897 & & & & & & & \\
\hline HRCAP & 0.669 & 0.888 & & & & & & \\
\hline INFOCAP & 0.667 & 0.526 & 0.777 & & & & & \\
\hline NPDCAP & 0.506 & 0.451 & 0.313 & 0.850 & & & & \\
\hline ORGPLAN & 0.611 & 0.676 & 0.711 & 0.333 & 0.787 & & & \\
\hline RELACAP & 0.595 & 0.533 & 0.722 & 0.398 & 0.606 & 0.847 & & \\
\hline SATISFEP & 0.257 & 0.327 & 0.491 & 0.228 & 0.459 & 0.391 & 0.768 & \\
\hline STREXPOP & 0.108 & 0.206 & 0.177 & 0.347 & 0.111 & 0.168 & 0.269 & 0.818 \\
\hline
\end{tabular}

When each measuring item correlates weakly with all other constructs save one with which it is theoretically connected, discriminant validity is demonstrated. When the correlation of the latent variable score with the measurement item must indicate an adequate pattern of loading, in which the measurement item loads heavily on their theoretically assigned component but not heavily on others. In this example, all pattern loadings were much more appropriate than cross-loading or other factors. No indicator variable should, at a bare minimum, have a stronger correlation with another latent variable than with its own latent variable. If it does, the model has been provided incorrectly.

Table 4. Discriminate validity

\begin{tabular}{lcccccccc}
\hline & FIRMLO & HRCAP & INFOCAP & NPDCAP & ORGPLAN & RELACAP & SATISFEP & STREXPOP \\
\hline FLO-1 & 0.931 & 0.581 & 0.558 & 0.398 & 0.520 & 0.545 & 0.153 & 0.048 \\
FLO-2 & 0.899 & 0.550 & 0.629 & 0.371 & 0.512 & 0.454 & 0.238 & 0.016 \\
FLO-3 & 0.933 & 0.671 & 0.652 & 0.499 & 0.630 & 0.558 & 0.251 & 0.087 \\
FLO-4 & 0.820 & 0.586 & 0.548 & 0.537 & 0.515 & 0.570 & 0.275 & 0.235 \\
HR-2 & 0.671 & 0.900 & 0.481 & 0.353 & 0.599 & 0.506 & 0.275 & 0.251 \\
HR-3 & 0.510 & 0.875 & 0.452 & 0.455 & 0.603 & 0.437 & 0.309 & 0.108 \\
IC-1 & 0.447 & 0.425 & 0.740 & 0.139 & 0.607 & 0.478 & 0.543 & 0.127 \\
IC-2 & 0.473 & 0.347 & 0.731 & 0.307 & 0.430 & 0.552 & 0.226 & 0.127
\end{tabular}




$\begin{array}{lllllllll}\text { IC-3 } & 0.638 & 0.433 & 0.853 & 0.322 & 0.575 & 0.667 & 0.298 & 0.159 \\ \text { NPD-2 } & 0.405 & 0.281 & 0.295 & 0.774 & 0.209 & 0.253 & 0.110 & 0.242 \\ \text { NPD-4 } & 0.457 & 0.457 & 0.256 & 0.920 & 0.336 & 0.400 & 0.251 & 0.336 \\ \text { OP-1 } & 0.541 & 0.664 & 0.633 & 0.439 & 0.843 & 0.511 & 0.413 & 0.125 \\ \text { OP-2 } & 0.429 & 0.426 & 0.401 & 0.187 & 0.744 & 0.370 & 0.343 & -0.092 \\ \text { OP-3 } & 0.462 & 0.474 & 0.610 & 0.122 & 0.771 & 0.529 & 0.323 & 0.185 \\ \text { RC-1 } & 0.412 & 0.342 & 0.495 & 0.273 & 0.387 & 0.827 & 0.162 & 0.119 \\ \text { RC-2 } & 0.478 & 0.482 & 0.633 & 0.270 & 0.561 & 0.883 & 0.455 & 0.256 \\ \text { RC-3 } & 0.605 & 0.497 & 0.676 & 0.466 & 0.549 & 0.828 & 0.304 & 0.023 \\ \text { SEP-1 } & 0.088 & 0.141 & 0.155 & 0.355 & 0.053 & 0.228 & 0.910 & 0.274 \\ \text { SEP-5 } & 0.094 & 0.227 & 0.137 & 0.182 & 0.161 & -0.007 & 0.714 & 0.143 \\ \text { SwEP-1 } & 0.260 & 0.407 & 0.456 & 0.260 & 0.484 & 0.337 & 0.308 & 0.803 \\ \text { SwEP-3 } & 0.146 & 0.117 & 0.281 & 0.070 & 0.176 & 0.147 & 0.095 & 0.708 \\ \text { SwEP-4 } & 0.160 & 0.158 & 0.357 & 0.149 & 0.324 & 0.373 & 0.164 & 0.788\end{array}$

In an ideal world, factor structure is simple, which means that planned loadings should be bigger than 0.7. (Some use 0.6). The indicators in the table above are all loaded correctly on their intended factors. The significance of factor labels is diminished by the lack of a clear factor structure (for example, the re-patronage factor still has significant cross-loadings with the indicators $\mathrm{f}$ and $\mathrm{g}$ ). Hair et al. (2017) proposed using a bootstrapping approach with a resample of 5,000 to assess the structural model by looking at the R2, beta $(\beta)$, and matching t-values. They also proposed that researchers should disclose the effect sizes in addition to these fundamental measures (f2). According to Sullivan and Feinn (2012), a p-value can tell you whether or not there is an effect, but it can't tell you how strong it is.

To assess the structural model, Hair et al. (2017) suggested looking at the $\mathrm{R}^{2}$, beta ( $\beta$ ) and the corresponding t-values via a bootstrapping procedure with a resample of 5,000. They also suggested that in addition to these basic measures researchers should also report the effect sizes (f2). As asserted by Sullivan and Feinn (2012), while a $p$-value can inform the reader whether an effect exists, the $p$-value will not reveal the size of the effect. In reporting and interpreting studies, both the substantive significance (effect size) and statistical significance ( $p$-value) are essential results to be reported (p.279).

Table 5. Quality criteria

\begin{tabular}{lcc}
\hline & R Square & R Square Adjusted \\
\hline HRCAP & 0.448 & 0.446 \\
INFOCAP & 0.509 & 0.506 \\
NPDCAP & 0.205 & 0.199 \\
ORGPLAN & 0.373 & 0.371 \\
RELACAP & 0.395 & 0.390 \\
SATISFEP & 0.248 & 0.239 \\
STREXPOP & 0.126 & 0.116 \\
\hline
\end{tabular}

The $\mathrm{R}^{2}$ values for each endogenous variable indicate how much variance is explained by the model (Lages et al., 2009a). The condition $R^{2}$ conditions were met by all endogenous variables. The overall model, on the other hand, explained 45 percent of the variance in human resources, 51 percent in information capability, 40 percent in relationship competence, and 21 percent in new product development.

\section{Hypothesis Testing}

As seen in Table 6, eight (8) out of the fourteen (14) proposed hypotheses were supported, while with the bootstrap t-values for six paths and their respective path coefficients, failed to achieve the recommended cut offs. 
Table 6. Hypothesis Testing

\begin{tabular}{llccccl}
\hline Hypothesis & Path & $\begin{array}{c}\text { B path } \\
\text { coefficient }\end{array}$ & $\begin{array}{c}\text { Standard } \\
\text { Deviation } \\
\text { (STDEV) }\end{array}$ & T Statistics & $\begin{array}{c}\text { P } \\
\text { Values }\end{array}$ & Decision \\
\hline H-1 & FIRMLO -> HRCAP_ & 0.669 & 0.028 & 23.89 & 0.000 & Supported \\
H-2 & FIRMLO -> OPCAP & 0.611 & 0.036 & 16.97 & 0.000 & Supported \\
H-3 & HRCAP_ - INFCAP & 0.082 & 0.073 & 1.12 & 0.259 & NOT Supported \\
H-4 & HRCAP_ - RELCAP & 0.227 & 0.067 & 3.39 & 0.001 & Supported \\
H-5 & HRCAP_ - NPDCAP & 0.417 & 0.053 & 7.87 & 0.000 & Supported \\
H-6 & OPCAP -> INFCAP & 0.656 & 0.053 & 12.38 & 0.000 & Supported \\
H-7 & OPCAP -> RELCAP & 0.452 & 0.064 & 7.06 & 0.000 & Supported \\
H-8 & OPCAP -> NPDCAP & 0.051 & 0.070 & 0.73 & 0.468 & Not Supported \\
H-9 & INFCAP -> STREPOP & 0.099 & 0.126 & 0.79 & 0.431 & Not Supported \\
H-10 & INFCAP -> SATISFEP & 0.431 & 0.076 & 5.67 & 0.000 & Supported \\
H-11 & RELCAP -> STREPOP & -0.035 & 0.154 & -0.23 & 0.820 & Not Supported \\
H-12 & RELCAP -> SATISFEP & 0.050 & 0.103 & 0.49 & 0.625 & Not Supported \\
H-13 & NPDCAP -> STREPOP & 0.330 & 0.063 & 5.24 & 0.000 & Supported \\
H-14 & NPDCAP -> SATISFEP & 0.073 & 0.042 & 1.74 & 0.086 & Not Supported \\
\hline
\end{tabular}

\section{Conceptual Framework and Results of Research Hypotheses}

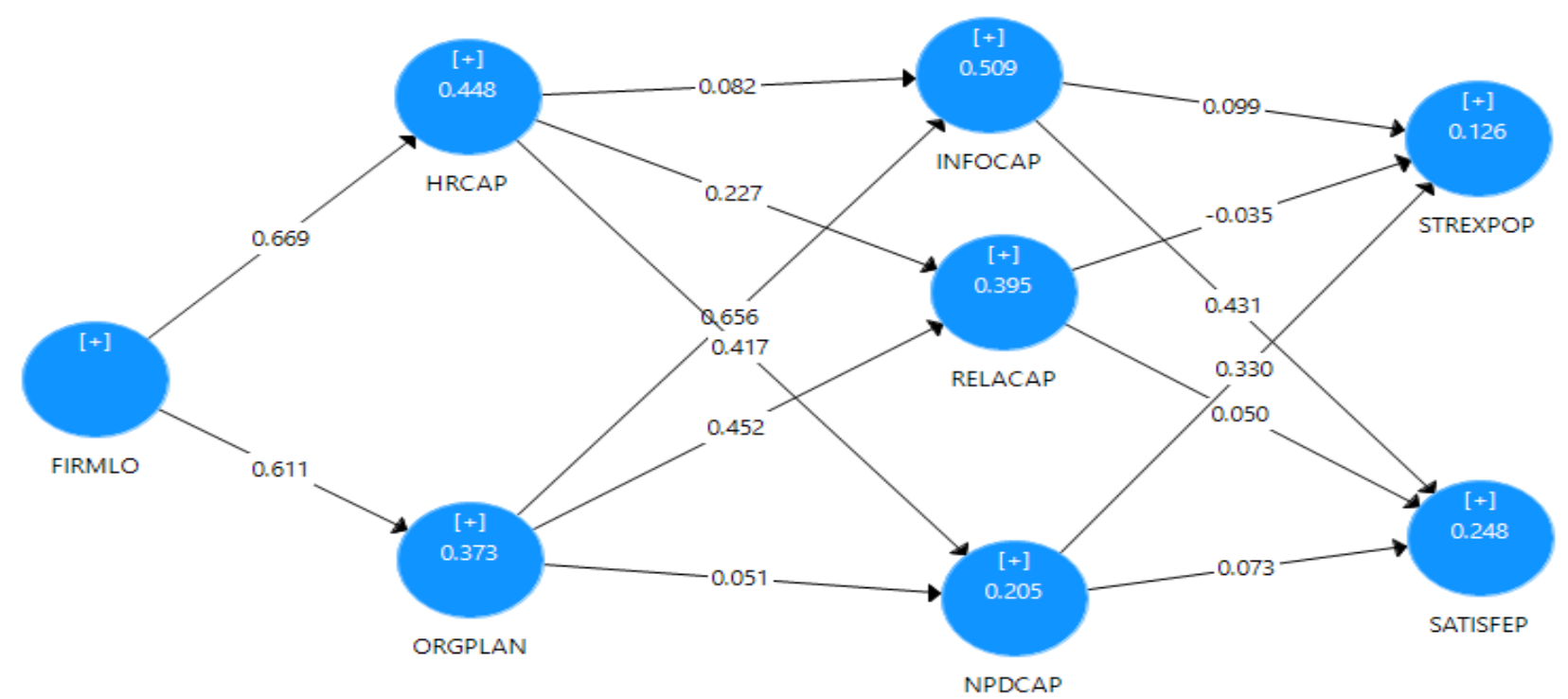

Figure 4. Result of role of firm location on export performance

Note: FIRM;-‘firm location', HRCAP: - 'human resource capability', OPCAP: - 'organizational planning capability', INFCAP: - 'information capability', RELCAP: - 'relationship capability' and NPDCAP: - 'new product development capability', STREXPOP: 'strategic export performance and SATISFEP: - 'satisfaction with export performance'. 


\section{Discussion of Hypothesis Results}

The geographic location of a company has a considerable and beneficial impact on human resource capability $(0.67$, p0.001). As a result, $\mathrm{H} 1$ is supported. The findings of $\mathrm{H} 1$ of this study are congruent with those of Mittelstaedt et al. (2006), who indicate that exporters in metropolitan regions benefit from a greater selection of business services and a better educated workforce. Organizational planning is significantly influenced by the location of the firm (0.611, p0.001). As a result, $\mathrm{H} 2$ is supported. H2 agrees with the findings of (Edelman et al., 2002), who claim that enterprises in remote areas may have insufficient or unavailable resources, limiting their range of strategic options.

Information capability was not significantly influenced by human resources Capability $(0.082, \mathrm{P}>0.259)$. As a result, H3 is rejected. This is in contrast to (Fung et al., 2007), who claim that a lack of company resources to acquire and utilize export market knowledge will lead to exporting firms making judgments based on gut instinct rather than informed strategic decision making.

The capability of human resources has a considerable and favourable impact on the capability of new product development $(0.417, \mathrm{p} 0.001)$. As a result, $\mathrm{H} 4$ is acceptable. This finding is in line with the findings of (Chen and Huang, 2009), who claimed that human capital enables businesses to improve their distinctive talents in order to generate new goods and increase their innovativeness. Human resources capability has a significant and positive influence on relationship capability $(0.366, \mathrm{p}<0.001)$.Hence H5 is accepted. This is consistent with (Freeman et al., 2006; Leonidou, 2003; Leonidou et al., 2002) who suggested that human resource capability are critical in developing the capabilities to identify, qualify, develop and maintain solid relationships with overseas agents to achieve superior export performance.

Organizational planning capability has a significant and positive influence on information capability $(0.656, \mathrm{p}<0.001)$ $(0.452, \mathrm{p}<0.001)$. Hence, $\mathrm{H} 6$ is supported. Oorganizational planning capability has a significant and positive influence on relationship capability $(0.452, \mathrm{p}<0.001)$. Hence, $\mathrm{H} 7$ is supported. The result is consistent with (Huang et al., 2002; Leonidou, 2004; Leonidou, 1998) who argued that strategic planning helps firms to develop, manage appropriate networks, alliances and implement export strategies efficiently and effectively. Organizational planning capability, on the other hand, did not have a significant influence on New Product Development Capability (0.051, $\mathrm{P}>0.468)$. Hence, $\mathrm{H} 8$ is rejected.

Strategic Export Performance was influenced by information capability $(0.099, \mathrm{P}>0.431)$. As a result, H9 was rejected. This is in contrast to (Souchon et al., 2012; Wolff and Pett, 2006), who suggest that enterprises with extensive export expertise and experience are more likely to attain higher levels of export performance. It also goes against (Dyer and Hatch, 2006; Gil, 2006).

Information competence, on the other hand, has a strong and positive impact on Satisfaction Export Performance (0.431, p0.01). As a result, H10 accepted. This is in contrast to (Goll et al., 2007; Loane and Bell, 2006; Srivastava et al., 1998), who argued that accumulating particular market information can help a firm gain a competitive advantage in international markets.

Strategic export performance (-0.035, P> 0.820) and satisfaction with Export Performance $(0.050, \mathrm{P}>0.625)$ were not significantly affected by relationship capability. As a result, H11 and H12 were rejected. The findings of this study contradict those of (Ural, 2009), who claimed that a focus on long-term relationships was statistically significant and beneficial to export performance.

Finally, New Product Development Capability influences strategic export performance significantly and positively $(0.330, \mathrm{p} 0.001)$. As a result, $\mathrm{H} 13$ was endorsed. The conclusions of this study are backed up by Crick and Spence (2005) and Lee et al. (2001), who found that SMEs rely heavily on creating relationships. The findings of this study are also in line with Morgan et al. (2004), who claimed that a firm's ability to give higher value to the target market is influenced by new product development capabilities. However, satisfaction export performance was not influenced by New Product Development Capability $(0.073, \mathrm{P}>0.086)$. As a result, H14 was rejected. This study's findings are congruent with those of (Piercy et al., 1998), who discovered that product development skills were not significantly associated with export performance. This result can be linked to the product's nature (coffee and sesames). New product development capability is thought to be one of the most important indications of a company's profitability and a source of competitive advantage (Schaefer, 1999).

\section{Conclusion}

Overall, the data showed that location organizational resources, organizational capabilities, and systems had a strong beneficial effect on competitive advantage, which improved export performance. A variety of resources and capacities have been investigated. Because of the increasing turbulence in the export market, a company's resources 
and competencies have become increasingly important. When compared to other exporters located in remote areas of the country, exporting firms located in metropolitan areas have a lower cost of access to foreign markets due to benefits such as specialized infrastructures, dense intellectual concentration, and network of suppliers, specialized labour, and concentration of existing exporters that can promote exporting to other firms in the same location.

\section{Implication of the Study}

Export performance is expected to suffer as a result of limited possibilities to develop resources and competencies in remote places. In other words, compared to their metropolitan counterparts, exporters in distant places are less likely to pursue export markets. Even if it enters into export markets the cost of making exports is much more expensive and costly. Examining the relationship between a company's location and its export performance is crucial for Revising government policies. To begin with, remote exporters face a scarcity of resources such as export-related services and networking opportunities. Second, distant exporters demand more personalized training and mentoring when it comes to export planning strategies. Thus, the government need to design special policies related to tariffs, taxes, agricultural inputs including fertilizer, seed, agricultural machineries, marketing infrastructures like telecom, financial institutions, building roads and upgrading existing roads, establishing training centres for the required manpower, opening government offices directly related to export process which includes customs, standard authorities etc. to assist the remote exporters to be competitive in international markets.

\section{Limitation and Direction for Future Study}

The study includes a number of flaws. For starters, this cross-sectional analysis is limited to two export sectors (coffee and sesame). As a result, other exporting enterprises were left out of the sampling frame. Second, this study is classified as a cross-sectional study that employs a quantitative approach. It had only measured the professional perception of exporter's firms at a specific point in time. As a result, future research should take into account other options.

The diversity of indicators to measure business performance renders it difficult to compare the results of different studies; that is, it is almost impossible to determine whether conflicting results are due to determinants (independent variables) or to the use of different scales of export performance (Zou et al., 1998). The data are collected on two agricultural products from one country and caution should be exercised when generalizing findings to other geographic regions.

\section{References}

Abera, H. (2009). Analysis of Sesame production, Supply, Demand and Marketing Issues in Ethiopia. Ethiopian Commodity Exchange Authority, Addis Abeba.

Anderson, J. C., \& Gerbing, D. W. (1988). Structural equation modeling in practice: a review and recommended two-step approach. Psychological Bulletin, 103(3), 411-423. https://doi.org/10.1037/0033-2909.103.3.411

Atherton, A., \& Hannon, P. (2006). Localised strategies for supporting incubation. Journal of Small Business and Enterprise Development, 13(1), 48-61. https://doi.org/10.1108/14626000610645306

Bakar, L. J. A., \& Ahmad, H. (2010). Assessing the relationship between firm resources and product innovation performance: a resource-based view. Business Process Management, 16(3), 420-435. https://doi.org/10.1108/14637151011049430

Barney, J. B. (1991). Firm resources and sustained competitive advantage. Journal of Management, 17(1), 99-120.

Barney, J. B. (2001a). Is the resource-based "view" a useful perspective for strategic management research? Yes. Academy of Management Review, 26, 41-56. https://doi.org/10.5465/amr.2001.4011938

Barney, J. B. (2001b). Resource-based theories of competitive advantage: A ten-year retrospective on the resource-based view. Journal of Management, 27, 643-650. https://doi.org/10.1177/014920630102700602

Barney, J. B. (2007). Gaining and sustaining competitive advantage (3rd ed.). Upper Saddle River, NJ: Pearson Education.

Barney, J. B., Wright, M., \& Ketchen, D. J. (2001). The resource based view of the firm: Ten years after 1991. Journal of Management, 27, 625-43. https://doi.org/10.1177/014920630102700601

Barney, J., Wright, M., \& Ketchen, D. (2001). The resource-based view of the firm: ten years after 1991. Journal of Management, 27(6), 625-641. https://doi.org/10.1177/014920630102700601

Bowen, D. E., \& Ostroff, C. (2004). Understanding HRM-Firm performance linkages: The role of the "strength" of 
the HRM system. Academy of Management Review, 29(2), 203-221.

Cadogan, J., Kuivalainen, O., \& Sandqvist, S. (2009). Export market-oriented behaviour and export performance: quadratic and moderating effects under differing degrees of market dynamism and internationalization. Journal of International Marketing, 17(4), 71-89. https://doi.org/10.1509/jimk.17.4.71

Cavusgil, S., \& Zou, S. (1994). Marketing strategy-performance relationship: an investigation of the empirical link in export market ventures. Journal of Marketing, 58(1), 1-21. https://doi.org/10.1177/002224299405800101

Chen, C., \& Huang, J. (2009). Strategic human resource practices and innovation performance - the mediating role of knowledge management capacity. Journal of Business Research, 62(1), 104-114.

Chin, W. (1998a). Issues and opinions on structural equation modeling. MIS Quarterly, 22(1), 7-16.

Chin, W. W. (1998b). The partial least squares approach to structural equation modeling. In Marcoulides, G. A. (Ed.), Modern Methods for Business Research (pp. 295-358). Erlbaum, Mahwah, NJ.

Clark, K., \& Fujimoto, T. (1991). Product Development Performance: Strategy, Organization and Management in the World Auto Industry. Harvard Business School Press, Boston, MA.

Colotla, I., Shi, Y., \& Gregory, M. J. (2003). Operation and Performance of international manufacturing networks. International Journal of Operations \& Production Management, 23(10), 1184-1206.

Costa Campi, M. T., Blasco, A., \& Marsal, E. (2004). The location of new firms and the life cycle of industries. Small Business Economics, 22(3/4), 265-281. https://doi.org/10.1023/B:SBEJ.0000022215.02146.40

Crick, D., \& Spence, M. (2005). The internationalisation of 'high performing' UK high-tech SMEs: a study of planned and unplanned strategies. International Business Review, 14(2), 167-185.

Davis, D. F., \& Mentzer, J. T. (2008). Relational resources in interorganizational exchange: the effects of trade equity and brand equity. Journal of Retailing, 84(4), 435-448. https://doi.org/10.1016/j.jretai.2008.08.002

De Brentani, U. (2001). Innovative versus incremental new business services: different keys for achieving success. The Journal of Product Innovation Management, 18(3), 169-187. https://doi.org/10.1111/1540-5885.1830169

De Toni, A., \& Nassimbeni, G. (2001). The export propensity of small firms: a comparison of organizational and operational management levers in exporting and non-exporting firms. International Journal of Entrepreneurial Behaviour \& Research, 7(4), 132-147. https://doi.org/10.1108/EUM0000000005762

Dyer, J., \& Hatch, N. (2006). Relation-specific capabilities and barriers to knowledge transfers: creating advantage through network relationships. Strategic Management Journal, 27(8), 701-719.

Edelman, L., Brush, C., \& Manolova, T. (2002). The impact of human and organizational resources on small firm strategy. Journal of Small Business and Enterprise Development, 9(3), 236-244. https://doi.org/10.1108/14626000210438562

Eisenhardt, K., \& Martin, J. (2000). Dynamic capabilities: what are they?. Strategic Management Journal, 21(10/11), 1105-1121. https://doi.org/10.1002/1097-0266(200010/11)21:10/11<1105::AID-SMJ133>3.0.CO;2-E

Fang, E., \& Zou, S. (2009). Antecedents and consequences of marketing dynamic capabilities in international joint ventures. Journal of International Business Studies, 40(5), 742-761. https://doi.org/10.1057/jibs.2008.96

Fornell, C., \& Larcker, D. F. (1981). Evaluating structural equation models with unobservable variables and measurement error. Journal of Marketing Research, 18, 39-50. https://doi.org/10.1177/002224378101800104

Freeman, J., Styles, C., \& Lawley, M. (2012). Does firm location make a difference to the export performance of SMEs?. International Marketing Review, 29(1), 88-113. https://doi.org/10.1108/02651331211201552

Fuller-Love, N., Midmore, P., \& Thomas, D. (2006). Entrepreneurship and rural economic development: a scenario analysis approach. International Journal of Entrepreneurial Behaviour \& Research, 12(5), 289-305.

Fung, P., Chen, I., \& Yip, L. (2007). Relationships and performance of trade intermediaries: an exploratory study. European Journal of Marketing, 41(1/2), 159-180. https://doi.org/10.1108/03090560710718166

Gefen, D., \& Straub, D. (2005). A practical guide to factorial validity using PL-Graph: Tutorial and annotated example. Communications of the Association for Information Systems, 16, 91-109.

Gholami, R., Sulaiman, A. B., Ramayah, T., \& Molla, A. (2013). Senior managers' perception on green information systems (IS) adoption and environmental performance: Results from a field survey. Information and Management, 50(7), 431-438. https://doi.org/10.1016/j.im.2013.01.004 
Gilmore, A., Carson, D., \& Rocks, S. (2006). Networking in SMEs: evaluating its contribution to marketing activity. International Business Review, 15(3), 278-293. https://doi.org/10.1016/j.ibusrev.2006.02.003

Goll, I., Johnson, N., \& Rasheed, A. (2007). Knowledge, capability, strategic change, and firm performance. Management Decision, 45(2), 161-179. https://doi.org/10.1108/00251740710727223

Gumede, V., \& Rasmussen, K. (2002). Small manufacturing enterprises and exporting in South Africa: a preliminary assessment of key export success factors. Journal of Small Business and Enterprise Development, 9(2), 162-171. https://doi.org/10.1108/14626000210427401

Hair, J. F., Hult, G. T. M., Ringle, C. M., \& Sarstedt, M. (2017). A Primer on Partial Least Squares Structural Equation Modeling (2nd ed.). Thousand Oaks: Sage. https://doi.org/10.15358/9783800653614

Helfat, C. E., \& Peteraf, M. A. (2003). The dynamic Resource-based View: Capability lifecycles. Strategic Management Journal, 24, 997-1010. https://doi.org/10.1002/smj.332

Hoogstra, G., \& van Dijk, J. (2004). Explaining firm employment growth: Does location matter?. Small Business Economics, 22(3/4), 179-192. https://doi.org/10.1023/B:SBEJ.0000022218.66156.ac

Hulland, J. (1999). Use of Partial Least Squares (PLS) in Strategic Management Research: A review of four recent $\begin{array}{lllll}\text { studies. } \quad \text { Strategic } & \text { Management }\end{array}$ https://doi.org/10.1002/(SICI)1097-0266(199902)20:2<195::AID-SMJ13>3.0.CO;2-7

Kaleka, A. (2002). Resources and capabilities driving competitive advantage in export markets: guidelines for industrial exporters. Industrial Marketing Management, 31(3), 273-283.

Katsikeas, C., \& Morgan, R. (1994). Differences in perceptions of exporting problems based on firm size and export market experience. European Journal of Marketing, 28(5), 17-35. https://doi.org/10.1108/03090569410062014

Katsikeas, C., Leonidou, L., \& Morgan, N. (2000). Firm-level export performance assessment: review, evaluation, and development. Journal of the Academy of Marketing Science, 28(4), 493-511.

Knight, G., \& Cavusgil, S. (2004). Innovation, organizational capabilities, and the born-global firm. Journal of International Business Studies, 35(2), 124-141. https://doi.org/10.1057/palgrave.jibs.8400071

La, V., Patterson, P., \& Styles, C. (2009). Client-perceived performance and value in professional B2B services: an international perspective. Journal of International Business Studies, 40(2), 274-300.

Lages, L., Silva, G., \& Styles, C. (2009a). Relationship capabilities, quality, and innovation as determinants of export performance. Journal of International Marketing, 17(4), 47-70. https://doi.org/10.1509/jimk.17.4.47

Lee, C., Lee, K., \& Pennings, J. (2001). Internal capabilities, external networks, and performance: a study on technology based ventures. Strategic Management Journal, 22(6/7), 615-640.

Leonidou, L., \& Theodosiou, M. (2004). The export marketing information system: an integration of the extant knowledge. Journal of World Business, 39(1), 12-36. https://doi.org/10.1016/j.jwb.2003.08.005

Loane, S., \& Bell, J. (2006). Rapid internationalisation among entrepreneurial firms in Australia, Canada, Ireland and New Zealand. International Marketing Review, 23(5), 467-485. https://doi.org/10.1108/02651330610703409

Makadok, R. (2001). Toward a synthesis of the resource-based and dynamic-capability views of rent creation. Strategic Management Journal, 22(5), 387-401. https://doi.org/10.1002/smj.158

Manolova, T., Brush, C., Edelman, L., \& Greene, P. (2002). Internationalization of small firms. International Small Business Journal, 20(1), 9-31. https://doi.org/10.1177/0266242602201003

Matanda, J., \& Freeman, S. (2009). Effect of perceived environmental uncertainty on exporter importer inter-organizational relationships and export performance improvement. International Business Review, 18(1), 89-107. https://doi.org/10.1016/j.ibusrev.2008.12.004

Mayer, K. J., \& Salomon, R. M. (2006). Capabilities, contractual hazards, and governance: Integrating resource-based and transaction cost perspectives. Academy of Management Journal, 49(5), 942-959.

Mittelstaedt, J., Ward, W., \& Nowlin, E. (2006). Location, industrial concentration and the propensity of small US firms to export. International Marketing Review, 23(55), 486-503. https://doi.org/10.1108/02651330610703418

Monitor Group. (2012). The Business Case for Investing in a Sesame Hulling Plant in Ethiopia.

Morgan, N. A., Kaleka, A., \& Katsikeas, C. S. (2004). Antecedents of export venture performance: A theoretical model and empirical assessment. Journal of Marketing, 68(1), 90-108. 
Morgan, R., \& Hunt, S. (1999). Relationship-based competitive advantage: the role of relationship marketing in marketing strategy. Journal of Business Research, 46(3), 281-290.

Ngo, L., \& O'Cass, A. (2009). Creating value offerings via operant resource-based capabilities. Industrial Marketing Management, 38(1), 45-59. https://doi.org/10.1016/j.indmarman.2007.11.002

Nonaka, I. (1991). The knowledge-creating company. Harvard Business Review, 69, 96-104.

Nuryakin, \& Ardyan, E. (2018). SMEs' marketing performance: The mediating role of market entry capability. Journal of Research in Marketing and Entrepreneurship, 20(2), 122-146. https://doi.org/10.1108/jrme-03-2016-0005

Nuryakin. (2018). Competitive advantage and product innovation: Key success of Batik SMEs marketing performance in Indonesia. Academy of Strategic Management Journal, 17(2), 1-17.

Oliver, C. (1997). Sustainable competitive advantage: Combining institutional and resource-based views. Strategic Management Journal, 18, 697-713.

Peng, M. W., \& Chen, H. (2009). Strategic responses to global institutional pressures in the Chinese toy industry. International Studies of Management and Organization.

Perez-Freije, J., \& Enkel, E. (2007). Creative tension in the innovation process: How to support the right capabilities. European Management Journal, 25(1), 11-24. https://doi.org/10.1016/j.emj.2006.11.005

Piercy, N., Kaleka, A., \& Katsikeas, C. (1998). Sources of competitive advantage in high performing exporting companies. Journal of World Business, 33(4), 378-393. https://doi.org/10.1016/S1090-9516(99)80081-9

Priem, R. L., \& Butler, J. E. (2001a). Is the resource-based "view" a useful perspective for strategic management research?. Academy of Management Review, 26, 22-40. https://doi.org/10.5465/amr.2001.4011928

Priem, R. L., \& Butler, J. E. (2001b). Tautology in the resource-based view and the implications of externally determined resource value: Further comment. Academy of Management Review, 26, 57-66.

Rahman, S. A., Amran, A., Ahmad, N. H., \& Taghizadeh, S. K. (2015). Supporting entrepreneurial business success at the base of pyramid through entrepreneurial competencies. Management Decision, 53(6), 1203-1223.

Rahman, S. A., Amran, A., Ahmad, N. H., \& Taghizadeh, S. K. (2016). Enhancing the wellbeing of base of the pyramid entrepreneurs through business success: the role of private organizations. Social Indicators Research, 127(1), 195-216. https://doi.org/10.1007/s11205-015-0951-4

Ramayah, T., Lee, J. W. C., Boey, J. C. I. (2011). Network collaboration and performance in the tourism sector. Service Business, 5(4), 411-428. https://doi.org/10.1007/s11628-011-0120-z

Ramayah, T., Yeap, J. A. L., \& Ignatius, J. (2013). An empirical inquiry on knowledge sharing among academicians in higher learning institutions. Minerva: A Review of Science, Learning and Policy, 51(2), 131-154.

Ramsey, R., \& Sohi, R. (1997). Listening to your customers: the impact of perceived salesperson listening behavior on relationship outcomes. Journal of the Academy of Marketing Science, 25, 127-37.

Ray, G., Barney, J. B., \& Muhanna, W. A. (2004). Capabilities, business processes, and competitive advantage: Choosing the dependent variable in empirical tests of the resource-based view. Strategic Management Journal, 25, 23-37. https://doi.org/10.1002/smj.366

Ringle, C. M., Wende, S., \& Becker, J.-M. (2015). Smartpls 3. Bonningstedt: SmartPLS. Retrieved from http://smartpls.com

Robertson, C., \& Chetty, S. (2000). A contingency-based approach to understanding export performance. International Business Review, 9(2), 211-235. https://doi.org/10.1016/S0969-5931(99)00037-2

Santhapparaj, A. S., Sreenivasan, J., \& Loong, J. C. K. (2006). Competitive factors of semiconductor industry in Malaysia: The managers' perspectives. Competitiveness Review, 16(3\&4), 197-211.

Saunders, M. N., \& Lewis, P. (2012). Doing research in business \& management: An essential guide to planning your project. Pearson.

Shoham, A., Evangelista, F., \& Albaum, G. (2002). Strategic firm type and export performance. International Marketing Review, 19(3), 236-258. https://doi.org/10.1108/02651330210430686

Shrader, R., \& Siegel, D. (2007). Assessing the relationship between human capital and firm performance: evidence from technology-based new ventures. Entrepreneurship Theory and Practice, 31(6), 893-908. 
Sirmon, D. G., Hitt, M. A., \& Ireland, R. D. (2007). Managing firm resources in dynamic environments to create value: Looking inside the black box. Academy of Management Review, 32(1), 273-292.

Slotegraaf, R., \& Dickson, P. (2004). The paradox of a marketing planning capability. Academy of Marketing Science Journal, 32(4), 371-385. https://doi.org/10.1177/0092070304265217

Smirnova, M., Naudi, P. P., Henneberg, C., Mousza, S., \& Koutchuch, S. P. (2011). The impact of Market orientation on the development of relational capability and performance outcomes: The case of Russian industrial firms. Industrial Marketing Management, 40(1), 44-54.

Souchon, A., Sy-Changco, J., \& Dewsnap, B. (2012). Learning orientation in export functions: impact on export growth. International Marketing Review, 29(2), 175-202. https://doi.org/10.1108/02651331211216970

Sousa, C., Martinez-Lopez, F., \& Coelho, F. (2008). The determinants of export performance: a review of the research in the literature between 1998 and 2005. International Journal of Management Reviews, 10(4), 343-374. https://doi.org/10.1111/j.1468-2370.2008.00232.x

Srivastava, R., Shervani, T., \& Fahey, L. (1998). Market-based assets and shareholder value: a framework for analysis. Journal of Marketing, 62(1), 2-18. https://doi.org/10.1177/002224299806200102

Styles, C., \& Ambler, T. (2000). The Impact of relational variables on export performance: an empirical investigation in Australia and the UK. Australian Journal of Management, 25(3), 261-281.

Subramaniam, M., \& Youndt, M. (2005). The influence of intellectual capital on the types of innovative capabilities. Academy of Management Journal, 48(3), 450-463. https://doi.org/10.5465/amj.2005.17407911

Sullivan, G. M., \& Feinn, R. (2012). Using Effect Size - or why the p Value is not enough. Journal of Graduate Medical Education, 4(3), 279-282. https://doi.org/10.4300/JGME-D-12-00156.1

Teece, D., Pisano, G., \& Shuen, A. (1997). Dynamic capabilities and strategic management. Strategic Management Journal, $18(7)$, https://doi.org/10.1002/(SICI)1097-0266(199708)18:7<509::AID-SMJ882>3.0.CO;2-Z

Toften, K. (2005). The influence of export information use on export knowledge and performance. Marketing Intelligence \& Planning, 23(2), 200-219. https://doi.org/10.1108/02634500510589949

Ural, T. (2009). The effects of relationships quality on export performance. European Journal of Marketing, 43(1/2), 139-168. https://doi.org/10.1108/03090560910923274

Wang, Y., \& Lo, H. (2003). Customer-focused performance and the dynamic model for competence building and leveraging: A resource-based view. Journal of Management Development, 22(6), 483-526.

Werts, C. E., Linn, R. L., \& Jöresko, K. G. (1974). Intraclass reliability estimates: Testing structural assumptions. Educational and Psychological Measurement, 34(1), 25-33. https://doi.org/10.1177/001316447403400104

Westhead, P., Wright, M., \& Ucbasaran, D. (2002). International market selection strategies selected by 'micro' and 'small' firms. The International Journal of Management Science, 30(1), 51-68. https://doi.org/10.1016/S0305-0483(01)00056-1

Wiklund, J., \& Shepherd, D. (2003). Knowledge-based resources, entrepreneurial orientation, and the performance of small and medium-sized businesses. Strategic Management Journal, 24, 1307-1314. https://doi.org/10.1002/smj.360

Wu, L-Y. (2006). Resources, dynamic capabilities and performance in a dynamic environment: perceptions in Taiwanese IT enterprises. Information and Management, 43(4), 447-454. https://doi.org/10.1016/j.im.2005.11.001

Zou, S., Taylor, C., \& Osland, G. (1998). The EXPERF Scale: a cross-national generalized export performance measure. Journal of International Marketing, 6(3), 37-58. https://doi.org/10.1177/1069031X9800600307

\section{Copyrights}

Copyright for this article is retained by the author(s), with first publication rights granted to the journal.

This is an open-access article distributed under the terms and conditions of the Creative Commons Attribution license (http://creativecommons.org/licenses/by/4.0/). 